\title{
CLASSIFICATION FEATURES OF TOWED UNDERWATER SYSTEMS AS AN INFORMATION COMPONENT OF EARLY STAGES THEIR DESIGN
}

\author{
КЛАСИФІКАЦЙНІ ОЗНАКИ БУКСИРУВАНИХ ПІДВОДНИХ СИСТЕМ \\ ЯК ІНФОРМАЦЙНИЙ СКЛАДНИК РАННІХ СТАДІЙ ЇХ ПРОЕКТУВАННЯ
}

\author{
Pavlo S. Kutsenko \\ arcadia.blacksea@gmail.com \\ ORCID: 0000-0003-0576-0503
}

\author{
П. С. Куценко, \\ молодший науковий співробітник
}

\author{
Admiral Makarov National University of Shipbuilding, Mykolaiv \\ Начіональний університет кораблебудування імені адмірала Макарова, м. Миколаӥв
}

\begin{abstract}
Underwater towed systems are typical of underwater robotics, and their use is associated with the implementation of marine exploration, conservation, research and other underwater work. Strict market requirements for the competitiveness of newly created underwater robotics stimulate the search for ways to reduce the cost of project resources for the creation of such equipment. In particular, it is important to increase the reliability of design decisions in the early stages of its design through the introduction of computer modeling methods and widespread use of artifact designs of elements, components and components of previously created towed underwater systems.

The use of such information in design practice involves the creation of an appropriate system of classification of towed underwater systems as an information basis for the early stages of design.

The aim of the work is to improve the existing classification of towed underwater systems based on a systems approach as an information basis for design in the early stages of their development.

To achieve this goal, a systematic approach was used in the formation of additional classification features, set theory in the formation of new classification features of towed underwater systems.

The result is a set of additional features that are essential for the design of new marine robotics, and those that form the information basis for operational use in design practice and, thus, increase the overall productivity of the design of towed underwater systems.

The scientific novelty is to improve the classification of towed underwater systems based on the application of a systems approach by introducing four system groups of classification features: functional, energy, information and design features.

This forms the information basis for improving the efficiency of design work in the early stages of development of towed underwater systems.

The practical significance of the study is to create a theoretical basis for further development of a database of elements, components and components of artifact designs of such systems, the use of which will reduce project resource costs and increase the competitiveness of towed marine equipment.
\end{abstract}

Key words: towed underwater system; classification; system approach; design.

Анотація. Підводні буксирувані системи належать до типових засобів підводної робототехніки, а їх застосування пов'язане з виконанням морських пошукових, природоохоронних, науково-дослідних та інших підводних робіт. Жорсткі ринкові вимоги щодо конкурентоспроможності новостворюваних засобів підводної робототехніки стимулюють пошук шляхів зменшення витрат проєктних ресурсів на створення такої техніки. Зокрема, актуальним є підвищення достовірності проєктних рішень уже на ранніх стадіях її проєктування шляхом упровадження методів комп'ютерного моделювання та широкого використання артефактних проєктів елементів, вузлів і компонентів раніше створених буксируваних підводних систем. Використання такої інформації у проєктній практиці передбачає створення відповідної системи класифікації буксируваних підводних систем як інформаційної основи для ранніх стадій проєктування.

Метою роботи є вдосконалення наявної класифікації буксируваних підводних систем на основі системного підходу як інформаційного підгрунтя проєктування на ранніх стадіях їх розроблення.

Для досягнення поставленої мети використано системний підхід під час формування додаткових класифікаційних ознак, теорію множин під час формування нових класифікаційних ознак буксируваних підводних систем. Результатом роботи є множина додаткових ознак, суттєвих для проєктування нової морської робототехніки, 
й таких, що утворюють інформаційне підгрунтя для оперативного використання у проєктній практиці і, відповідно, забезпечують підвищення загальної продуктивності процесів проєктування буксируваних підводних систем.

Наукова новизна полягає в удосконаленні класифікації буксируваних підводних систем на основі застосування системного підходу шляхом уведення чотирьох системних груп класифікаційних ознак: функціональних, енергетичних, інформаційних і конструктивних. Це утворює інформаційне підгрунтя для підвищення ефективності проєктних робіт на ранніх стадіях розроблення буксируваних підводних систем.

Практична значимість дослідження полягає у створенні теоретичного підгрунтя для подальшого розроблення бази даних елементів, вузлів і компонентів артефактних проєктів таких систем, використання яких зменшить витрати ресурсів проєкту та сприятиме підвищенню конкурентоздатності створюваних засобів буксируваної морської техніки.

Ключові слова: буксирувана підводна система, класифікація, системний підхід, проєктування.

\section{ПОСТАНОВКА ЗАДАЧІ}

Підводні буксирувані системи (БПС, в англомовній літературі - Underwater Towed System) належать до найбільш поширених видів підводної техніки й широко застосовуються для дослідження й освоєння Світового океану [1-5]. Порівняно 3 іншими видами такої техніки, вони забезпечують максимально високу продуктивність під час обстеження водної товщі й донної поверхні, оскільки швидкості буксирування становлять зазвичай 6-12 вузлів і більше [6].
Типова БПС розташовується на судні-буксирувальнику (СБ) і складається з буксируваного підводного апарата (БПА), кабель-буксира (КБ), спуско-піднімального пристрою (СПП), кабельної лебідки (КЛ) та поста енергетики й керування (ПЕК) [2] (рис. 1,a). У складних варіантах застосування до складу БПС входять декілька БПА та КБ (рис. 1,б).

На СБ розташовані кабельна лебідка (КЛ) та пост енергетики і керування (ПЕК). ПЕК призначений для одержання й аналізу інформації, яка надходить

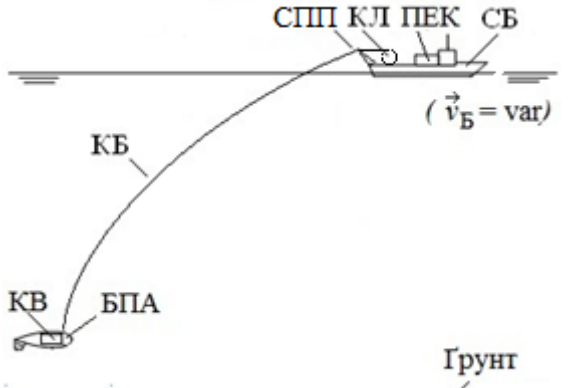

$a$

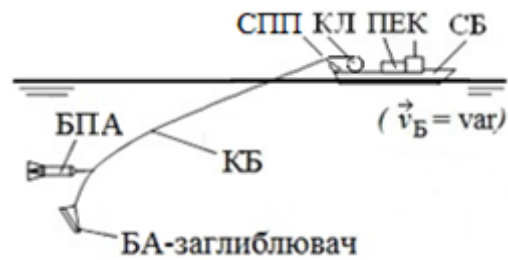

B

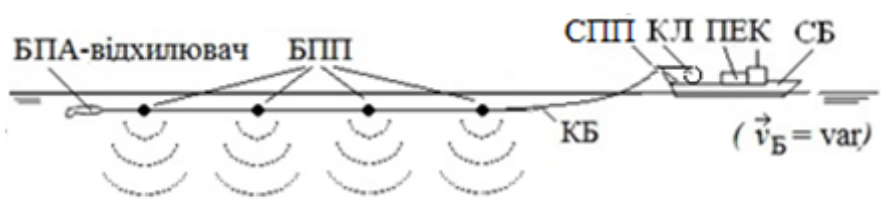

Грунг

$\sigma$
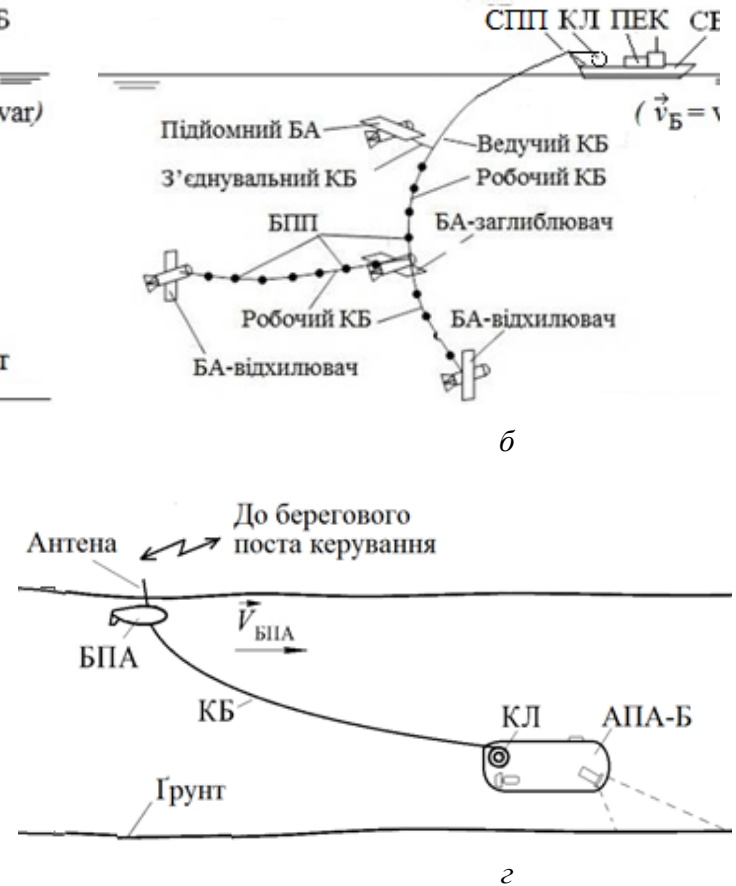

$\partial$

Рис. 1. Типовий склад буксируваних підводних систем 


\section{СУДНОБУДУВАННЯ № 4ロ 2020}

iз БПА, генерування керівних сигналів і розподілу енергії, яка потрібна для роботи БПС (БПА і КЛ). За допомогою КЛ здійснюються спуск та підйом БПА, попущення-вибирання КБ.

На СБ розташовано також спуско-піднімальний пристрій (СПП), за допомогою якого виконуються операції вивантаження БПА з борту СБ на воду перед початком місії та підйом БПА на борт СБ після закінчення місії.

Характерною особливістю БПС $є$ наявність гнучкого зв'язку у вигляді тросу або буксирного кабелю між СБ і БПА, який служить для буксирування БПА, керування ним і передачі інформації в реальному часі. Водночас інформація, яка одержується, дає змогу виконувати оперативне дистанційне керування БПА. Іноді КБ застосовується як вантажний елемент для спуску-підйому БПА.

До процесу та результатів проєктування сучасних БПС висувається низка вимог, які стосуються, загалом, скорочення термінів їх проєктування та будівництва i, як кінцевий результат, підвищення конкурентоздатності новостворених БПС як наукомісткої продукції на внутрішньому і зовнішніх ринках морської робототехніки [7; 8]. Тому на цей час актуальним $\epsilon$ прикладне наукове завдання підвищення ефективності проєктних робіт зі створення нових БПС.

\section{АНАЛІЗ ОСТАННІХ ДОСЛІДЖЕНЬ І ПУБЛІКАЦІЙ}

Зазначимо, що питання вдосконалення проєктування БПС шляхом впровадження сучасних методів проєктування завжди було в центрі наукових інтересів дослідників. До головних питань дослідників відносились традиційні питання систем автоматизованого проєктування [9], автоматизація керування режимами роботи БПС [10], контролю динамічних процесів в елементах системи [11; 12].

Досліджуються також питання керування буксирними кабельними лебідками як складовими БПС. Так, у роботі [13] представлено ефективний підхід до планування буксирувальних маневрів для БПА за допомогою управління СБ і КЛ. Доведено, що можна сформувати буксирну траєкторію для БПА таким чином, щоб він рухався за необхідною траєкторією в умовах зовнішніх збурень.

У роботі [14] виконано системний аналіз закономірностей розвитку технологій проєктування БПС та сформульовано перспективні напрямки їх удосконалення на основі сучасного інструментарію проєктування та забезпечення конкурентоспроможності на ринку морської техніки.

Однак питання класифікації БПС та можливого ii удосконалення з метою підвищення ефективності проєктування та забезпечення конкурентоздатності новостворених БПС як наукомісткої продукції на внутрішньому і зовнішніх ринках морської робототехніки в них не розглядаються.

\section{ВІДОКРЕМЛЕННЯ НЕ ВИРІШЕНИХ РАНІШЕ ЧАСТИН ЗАГАЛЬНОЇ ПРОБЛЕМИ}

Одним із напрямів підвищення ефективності проєктування та забезпечення конкурентоздатності БПС $€$ можливість приймати достовірні проєктні рішення вже на ранніх стадіях проєктування (технічна пропозиція, передескізні проєктні розробки) шляхом упровадження методів комп'ютерного моделювання та використання результатів раніше виконаних проєктів [8]. Оскільки проєктування ведеться значною мірою «за прототипом», тобто з використанням артефактних проєктів, доцільним $є$ перенесення їхніх результатів і використання типових проєктних рішень на ранніх стадіях проєктування. Це має забезпечити зниження собівартості проєктних робіт зі створення БПС загалом завдяки скороченню термінів виконання етапів ескізного та технічного проєктів.

Однак для обгрунтованого ухвалення проєктних рішень на ранніх стадіях проєктування необхідно створити відповідну базу даних типових та/чи апробованих практикою інноваційних технічних рішень по вузлах і компонентах реально створених БПС та розробити систему автоматизації конструкторських робіт згідно концепції Shipbuilding 4.0 [15], яка б спиралась на уточнену класифікацію БПС на основі системного підходу $[16,17]$ i, тим самим, давала б змогу оперативно аналізувати наявні на ринку елементів підводної робототехніки технічні рішення та обгрунтовано включати їх у проєкт БПС, яка проєктується.

Зі свого боку, це дасть змогу формалізувати та знизити трудомісткість як процесу розроблення бази даних наявних елементів, вузлів і компонентів БПС, так і процесу власне проєктування нових БПС.

Отже, прикладна наукова задача уточнення існуючої класифікації БПС на основі системного підходу $\epsilon$ актуальною.

\section{МЕТА ДОСЛІДЖЕННЯ}

Метою дослідження є удосконалення класифікації буксируваних підводних систем на основі системного підходу як інформаційного підгрунтя проєктування на ранніх стадіях їх розроблення.

\section{МЕТОДИ, ОБ'ЄКТ ТА ПРЕДМЕТ ДОСЛІДЖЕННЯ}

Предметом дослідження є процес проєктування буксируваних підводних систем на ранніх стадіях їх розроблення.

Об'єктом дослідження є доцільність і можливість удосконалення класифікації буксируваних підводних систем на основі системного підходу та визначення іiі місця у проєктуванні таких систем на ранніх стадіях їх розроблення.

Методи дослідження: системний підхід під час формування додаткових класифікаційних ознак, теорія множин під час формування нових класифікаційних ознак буксируваних підводних систем. 


\section{ОСНОВНИЙ МАТЕРІАЛ \\ 1. Наявна класифікація та сфери застосування БПС}

Залежності від завдань, які розв'язують за допомогою БПС, $\epsilon$ велика різноманітність їхніх схем і конструкцій. Переважна більшість завдань пов'язана 3 виконанням підводного пошуку, рідше - 3 одночасним взяттям проб води і грунту або з доставкою корисного вантажу (КВ) в задану точку морського дна.

Водночас БПС повинна забезпечувати необхідну смугу пошуку й задане положення та умови роботи фото-, відео- чи гідроакустичної апаратури, яка виявляє підводні об'єкти.

Типовими завданнями БПС під час виконання морських робіт широкого призначення є:

- вимірювання гідрофізичних та гідрохімічних параметрів водного середовища (температури, електропровідності, кислотності, лужності та ін.);

- вивчення рельєфу й структури морського дна (гідроакустичне обстеження поверхні, глибинне профілювання морського дна й картографування);

- імпульсне зондування морського дна з метою пошуку корисних копалин на шельфі;

- гідроакустичний та відеопошук затонулих об'єктів.

До наведених вище підводних завдань в останні роки додається фото- і відеозйомка донної поверхні, основною вимогою якої є високоточне картографування, фото- і відеодокументування підводних об'єктів з їхньою географічною прив'язкою [18]. Такі роботи є невіддільною частиною прокладки підводних кабелів і трубопроводів, пошукових, аварійнорятувальних робіт і науково-дослідних вишукувань.

Згідно з усталеною міжнародною практикою [19; 20] за класифікаційними ознаками підводні апарати загалом і БПС зокрема поділяються на:

- населені (manned, $M$ ) і ненаселені (unmanned, $U$ );

- автономні (free, $F$ ) прив'язні (tethered, $T$ );

- плаваючі (suspended, $S$ ) і донні (buttomed, $B$ );

- самохідні (propelled, $P$ ) і несамохідні (inert, $I$ ).

Крім того, сучасні БПС можуть бути виконані за комбінованою схемою побудови (класифікаційна ознака - combined, $C$ ), коли до їх складу можуть входити ненаселені самохідні підводні апарати, що на певних етапах підводної місії можуть буксируватись.

Отже, типові БПС утворюють класифікаційну групу UTSI, .

У вітчизняній практиці класифікація БПС виконується також за ознаками призначення та структури просторової конфігурації БПС, схеми буксирування підводного апарата БПС та за робочою глибиною буксирування.

За призначенням П БПС поділяють на:

- пошукові $\Pi_{П}$, призначені для пошуку затонулих об'єктів - суден, авіа- та космічної техніки тощо [21]; типовими морськими операціями, які успішно проведені з застосуванням БПС, є пошук теплоходу «Титанік» за допомогою пошукового БПА Argo [22] та пошук затонулого підводного човна «Комсомолець» за допомогою БПА «Лортодромія-ІІІ ДВН» [18], оснащених гідролокаторами бічного огляду, магнітометрами та інші (рис. 1, $a$ та рис. 2,a,б);

- науково-дослідницькі $\Pi_{H}$, призначені для вивчення Світового океану (дослідження процесів розвитку іхтіофлори та іхтіофауни, донних відкладень), вирішення задач підводної археології та екології моря [24]; до таких систем належить БПА серії CAMPER [25] та Video Plankton Recorder [26] фірми WHOI (рис. 1,б та рис. 2,,,$e$ );

- рибопромислові $\Pi_{P}$, призначені для виявлення промислово значимих рибних косяків та їх вилову за допомогою тралів; до таких апаратів належать БПА «Тетіс», які можуть працювати у ненаселеному та населеному режимах [23] (рис. 2,6);

- БПС $\Pi_{3}$ радіо- та супутникового зв'язку населеного підводного апарата 3 базою без спливання на поверхню (рис. 1,2 та рис. 2,3);

- геологорозвідувальні $\Pi_{\Gamma}$, призначені для пошуку корисних копалин на шельфі за допомогою генерації у воду гідроакустичних імпульсів та їх прийому після відбиття від морського дна [21] (рис. 2,d);

- воєнні $\Pi_{B}$, призначені для пошуку, класифікації та картографування підводного середовища в оборонних цілях.

Множина класифікаційних ознак за призначенням П, таким чином, містить складові:

$$
\Pi=\left\{\Pi_{\Pi} ; \Pi_{H} ; \Pi_{P} ; \Pi_{3} ; \Pi_{\Gamma} ; \Pi_{B}\right\} .
$$

За структурою просторової конфігурації $C$ БПС поділяються на:

- одноланкові $C_{O}$, які містять один БПА, що буксирується за СБ за допомогою кабель-буксиру (КБ); такі БПС є найбільш розповсюдженими 3-за їхньої простоти побудови й експлуатації, рис. $1, a$;

- багатоланкові $C_{b}$, до складу яких входять декілька БПА або буксируваних пошукових приладів (БПП), які буксируються одним спільним КБ або окремими КБ і використовують БПА-відхилювачі, БПА-заглиблювачі та підйомні БПА для розгортання БПС у просторову робочу схему, рис. 1,б.

Множина класифікаційних ознак за структурою просторової конфігурації $C$, відповідно, містить складники:

$$
C=\left\{C_{O} ; C_{B}\right\} .
$$

За схемою буксирування $Б$ БПС поділяють на:

- глибинного буксирування $Б_{\Gamma ь}$ (надводне чи підводне СБ буксирує БПА у товщі води); така схема буксирування застосовується при виконанні наукових досліджень, а також при підводних пошукових роботах (рис. 1,a);

- буксирування просторово розгалуженого комплексу пошукових і вимірювальних приладів для 


\section{СУДНОБУДУВАННЯ № 4ロ 2020}

об’ємного дослідження водної товщі у наукових, природоохоронних чи інших цілей (рис. 1.б);

- придонного буксирування $Б_{\text {ДБ }}$ (надводне судно буксирує БПА у безпосередній близькості до донної поверхні); буксирування застосовується при виконання пошукових і аварійно-рятувальних робіт, при проведенні протимінних морських операцій, а також при проведенні підводних наукових досліджень (рис. 1,6);

- приповерхневого «зворотного» буксирування БПА $Б_{П з}$, коли підводне СБ (зазвичай, автономний населений підводний апарат) буксирує БПА-радіобуй під поверхнею моря для організації оперативного радіо- чи супутникового зв'язку з базою без спливання на поверхню моря (рис. 2,2);

- приповерхневого буксирування БПА $\delta_{П Б}$ за класичною схемою - надводне судно буксирує БПА або БПП по поверхні моря; зазвичай, у такий спосіб буксирують пошукову гідроакустичну апаратуру при пошуку підводних родовищ нафти і газу, рис. 1.д.

Отже, множина класифікаційних ознак за структурою просторової конфігурації $Б$ містить складники:

$$
\bar{B}=\left\{Б_{\Pi Б} ; Б_{\Pi 3} ; Б_{\Gamma Б} ; Б_{Д Б}\right\} .
$$

За робочою глибиною $Г$ БПС, як і інші підводні апарати і системи, поділяють на: БПС для малих глибин $\Gamma_{600}$ (до 600 м); БПС для середніх глибин $\Gamma_{2000}$ (до 2000 м); БПС для великих глибин $\Gamma_{6000}$ (до 6000 м); БПС для надвеликих глибин $\Gamma_{\text {мах }}$ (більше 6000 м).

За останні роки у роботі морських організацій спостерігається тенденція щодо збільшення пошукових на водолазних глибинах (до 60 м), тому автори вважають за доцільне виділити окремий підклас БПС для мілководних акваторій $\Gamma_{100}$ (до 100 м).

Отже, множина класифікаційних ознак за структурою просторової конфігурації 5 , містить складові:

$$
\Gamma=\left\{\Gamma_{100} ; \Gamma_{600} ; \Gamma_{2000} ; \Gamma_{000} ; \Gamma_{\text {Max }}\right\} .
$$

Наведені вище підходи до класифікації БПС є важливими, у першу чергу, для замовників такої техніки, оскільки дають змогу оцінити область їх застосування. Однак вони не містять інформації про конструкторські рішення, закладені у їх технічну реалізацію. Це не дає змоги визначити особливості побудови нових зразків морської буксируваної робототехніки та виконати порівняльний аналіз проєктних рішень.

2. Удосконалення класифікації БПС на основі системного підходу

Автор пропонує більш узагальнену класифікацію БПС, яка грунтується на системному підході [8] та передбачає чотири системні групи класифікаційних ознак: функціональні $\Phi$, енергетичні $E$, інформаційні $I$ та конструктивні $K$.

Тоді класифікаційні ознаки можна представити у вигляді множини $K O$ :

$$
K O=\{\Phi ; E ; I ; K\} .
$$

До функціональних ознак $\Phi$ доцільно віднести, власне, всі наведені вище вітчизняні класифікаційні ознаки (П, $C, Б, ~ Г)$, оскільки вони характеризують експлуатаційні можливості БПС. 3 огляду на специфіку морських операцій варто доповнити вказані ознаки суттєвою для проєктувальників БПС ознакою кратності застосування 3 таких систем - одноразового застосування $3_{O}$ та багаторазового застосування $3_{E}$ :

$$
3=\left\{3_{O} ; 3_{E}\right\} .
$$

Тоді множина $\Phi$ функціональних ознак БПС буде мати такі складники:

$$
\Phi=\{\Pi ; C ; Б ; \Gamma ; 3\} .
$$

До енергетичних ознак $E$, яка має створювана БПС, доцільно віднести такі:

$E_{K Б}$ - живлення БПА забезпечується через кабельбуксир;

$E_{A}$ - живлення БПА забезпечується джерелами живлення, розташованими на борту БПА (зазвичай, це - акумуляторні батареї);

$E_{K Б А}-$ живлення БПА забезпечується за змішаною схемою, коли одна частина споживачів електроенергії БПА живиться від бортових акумуляторних батарей (наприклад, системи навігації та керування), а інші від джерела енергії СБ через кабель-буксир (наприклад, підсистеми електрообладнання корисного вантажу БПА - пробовідбірників води, потужні гідроакустичні прилади, систем озброєння тощо).

Тоді множина $E$ енергетичних ознак БПС буде мати наступні складові:

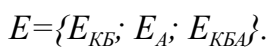

Важливим складником класифікаційних ознак сучасних БПС є інформаційні ознаки $I$, які характеризують рівень автоматизації БПС:

- під час підготовки до роботи $I_{\Pi}$ (наприклад, автоматичне тестування обладнання перед початком місіі) та після іiі завершення $I_{3}$;

- під час виконання підводної місії $I_{M}$ (наприклад, ручне керування БПС $I_{M-P}$, автоматизоване керування $I_{M-A}$, автоматичне керування $I_{M-A A}$, інтелектуальне керування $I_{M-I}$, групове керування декількома БПА або БПС $\left.I_{M-\Gamma p}\right)$.

Іншим складником інформаційної ознаки I є рівень інформатизації процесів, які мають місце при застосуванні БПС за призначенням - наявність та вид інформаційного обміну між БПА та ПЕК $I_{\text {БПА- }}$ пЕк або між БПА та іншими підводними системами $I_{\text {БПА-ПС }}$ (наприклад, автономними підводними апаратами чи донними станціями). Зазвичай це зв'язок через КБ $\left(I_{\text {БПА-ПЕК-КБ }}\right)$, гіДроаКУстИчНИЙ $\left(I_{\text {БПА-ПЕК-ГАКС }}, I_{\text {БПА-ПС- }}\right.$ ГАКС $)$ або оПтичний $\left(I_{\text {БПА-ПЕК-О}}, I_{\text {БПА-ПС-О }}\right)$ канали зв'язКУ.

Тоді множина $I$ інформаційних ознак БПС буде мати такі складники:

$$
\begin{gathered}
I=\left\{I_{\Pi} ; I_{3} ; I_{M-P} ; I_{M-A} ; I_{M-A A} ; I_{M-I} ; I_{M-Г P} ; I_{\text {БПА-ПЕК-КБ}} ;\right. \\
I_{\text {БПА-ПЕК-ГАКС }} ; I_{\text {БПА-ПС-ГАКС }} ; I_{\text {БПА-ПЕК-О }} ; I_{\text {БПА-ПС-О }} .
\end{gathered}
$$

Зазначимо, що в загальному випадку автоматизації підлягають усі складники БПС: 
- пристрій доставки БПА на воду та прийому 3 води (на надводних суднах та кораблях - це автоматичний спуско-піднімальний пристрій, на науководослідних підводних апаратах - це дистанційно керовані ангари 3 автоматичними кабельними лебідками для випускання і прийому БПА на ходу підводного апарата);

- кабельні лебідки для автоматичного завдання довжини попущеної частини КБ при усталеному русі БПА та керованої зміни довжини КБ у перехідних режимах експлуатації БПС;

- виконавчі механізми власне БПА - приводи повороту несучих поверхонь (крил БПА), елеронів (елевонів) і хвостового оперення, рушії позиціювання БПА тощо;

- виконавчі механізми корисного вантажу, встановленого на БПА - фото-, відео- і гідроакустичної апаратури, відбірників проб води і грунту тощо.

Розгляньмо тепер конструктивні ознаки класифікації БПС $K$. До них насамперед віднесемо:

- склад обладнання БПС $K_{\text {Обл }}$ (базова комплектація $K_{\text {Обл-Б, }}$, повна комплектація $K_{\text {Обл-П }}$, авіаційного $K_{\text {Обл- }}$ Авiа та підводного $K_{\text {обл-Пч }}$ застосування);

- конструктивні рішення складових БПС - архітектурно-конструктивний тип БПА $K_{\text {БПА }}$, конструктивні рішення щодо КЛ $K_{\kappa Л}$, КБ $K_{K Б}$, СПП $K_{C П п}$ та ПЕК $K_{\text {IEK }}$;

- характеристики механічної автономності БПА (тільки буксируваний $K_{L}$, 3 можливістю переходу до режиму телекерованого самохідного $K_{R O V}$ чи автономного самохідного $K_{A U V}$ підводного руху БПА);

- масо-габаритні характеристики обладнання

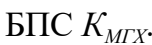

Тоді множина $K$ конструктивних ознак БПС буде мати такі складники:

$$
\begin{aligned}
& K=\left\{K_{\text {Обл-Б }} ; K_{\text {Обл-П }} ; K_{\text {Обл-Авіа }} ; K_{\text {Обл-Пч }} ; K_{\text {БПА }} ; K_{\text {КЛ }} ; K_{\text {КБ }} ;\right. \\
& \left.K_{C I I I} ; K_{\text {ПЕК }} ; K_{B} ; K_{R O V} ; K_{A U V} ; K_{M Г X\}}\right\}
\end{aligned}
$$

Зазначимо, що запропоновані класифікаційні ознаки насамперед притаманні як БПА, так і здебільшого іншим складникам БПС - їхнім кабельним лебідкам, кабель-буксирам і постам енергетики й керування.

3. Удосконалена класифікація буксируваних підводних систем як інформаційне підгрунтя проєктування на ранніх стадіях їх розроблення

Аналіз науково-технічної літератури та досвід авторів у проєктуванні та експлуатації засобів морської робототехніки свідчить, що магістральним шляхом до створення конкурентоспроможних БПС є підвищення достовірності технічних рішень вже на ранніх стадіях проєктування та скорочення витрат ресурсів, зокрема, часу на їх проєктування.

Успішне розв'язання вказаних завдань підвищить достовірність проєктних рішень на ранніх стадіях проєктування БПС забезпечить зменшення витрат часу на подальші стадії проєктування, сприятиме підвищенню конкурентоспроможності нової підводної техніки.

Уведення у проєктну практику удосконаленої класифікації БПС на основі застосування системного підходу шляхом уведення чотирьох системних груп класифікаційних ознак (функціональних, енергетичних, інформаційних та конструктивних) дасть можливість будувати бази даних артефактних і нових, що розробляються, проєктів елементів, вузлів і компонентів БПС, що забезпечить оперативне звернення до них, оцінку ступеня відповідності конкретним проєктним завданням і внесення до проєктів, що розробляються, 3 мінімальними витратами проєктних ресурсів.

Побудовані за пропонованими класифікаційними ознаками бази даних елементів, вузлів і компонентів БПС, таким чином, утворять інформаційне підгрунтя для організації високопродуктивного процесу проєктування БПС вже на ранніх стадіях їх розроблення.

\section{ОБГОВОРЕННЯ ОТРИМАНИХ РЕЗУЛЬТАТІВ}

Сучасний рівень проєктування ненаселених БПС характеризується добре розвинутими методами математичного моделювання та проєктними методами зі створення окремих складових буксируваних систем. Зокрема, створено широкий спектр проєктних методик для буксируваних підводних апаратів як твердих тіл у потоці води та їх кабель-буксирів як гнучких тіл у потоці води.

Проте невирішеними залишились завдання впровадження системного підходу на ранніх стадіях проєктування БПС. Його впровадження в організацію процесу проєктування БПС утворює методологічну основу для отримання конкурентних переваг створюваної продукції, оскільки враховує особливості взаємодії основних складових об'єкту проєктування в процесі його експлуатації.

Крім того, системний підхід передбачає інтеграцію кращих технологій проєктування, що забезпечує високу якість технічних рішень і суттєво зменшує витрати часу на проєктування.

Запропонована уточнена система класифікації БПС як наукомісткої продукції включає основні системні ознаки - функціональні, енергетичні, інформаційні та конструктивні, а їх використання при створення відповідних баз даних елементів, вузлів і компонентів БПС дає змогу конструкторам підводної техніки оперативно отримувати достовірну інформацію щодо артефактних проєктів БПС та використовувати іiі у своїй проєктній діяльності.

\section{ВИСНОВКИ}

1. На основі вивчення експлуатаційних характеристик буксируваних підводних систем, існуючої класифікації, складу обладнання та сучасних вимог ринку щодо конкурентоздатності запропоновано 


\section{СУДНОБУДУВАННЯ № 4- 2020}

удосконалену їх класифікацію на основі застосування системного підходу шляхом уведення чотирьох системних груп класифікаційних ознак - функціональних, енергетичних, інформаційних та конструктивних ознак, що утворює інформаційне підгрунтя для підвищення ефективності проєктних робіт на ранніх стадіях розроблення буксируваних підводних систем.

2. Для кожної з нових класифікаційних ознак запропоновано множину додаткових ознак, суттевих для проєктування нової морської робототехніки, та таких, що утворюють інформаційне підгрунтя для оперативного використання у проєктній практиці i, відповідно, забезпечують підвищення загальної про- дуктивності процесів проєктування буксируваних підводних систем.

3. Запропоновані класифікаційні ознаки буксируваних підводних систем дають змогу будувати бази даних елементів, вузлів і компонентів артефактних проєктів таких систем, використання яких зменшить витрати ресурсів проєкту та, загалом, підвищить конкурентоздатність створюваних засобів буксируваної морської техніки.

4. Подальші дослідження вбачається доцільним проводити в напрямі розроблення методики використання вдосконаленої класифікації буксируваних підводних систем у проєктній практиці на ранніх стадіях їх створення.

\section{REFERENCES}

[1] Pronin, A.A. (2017). Metodika sbora i predstavlenija materialov videosjomki poverchnosti dna s pomoshju neobitaemogo podvodnogo buksiruemodo apparata „Videomodul”. Negdunarodnyi jurnal prikladnych i fundamentalnych issledovaniy. V. 12-1. S. 142-147.

[2] Towed Vehicle: Undulating Platforms as Tools for Mapping Coastal Processes and Water Quality Assessment. Seaside, California, 2007. Workshop Proceeding. http://aquaticcommons.org/3106/1/ACT_WR07-01_Tower_Vehicles.pdf

[3] Frank Kirchner, Sirco Straube, Daniel Kuhn, Nina Nouer. Al Technologies for Underwater Robots. Springer Nature Switzerland AG, 2020. https://www.springer.com/gp/book/9783030306823

[4] Geotechnical \& Geophysical Investigations for Offshore and Nearshore Developments. (2005). International Society for Soil Mechanics and Geotechnical Engineering. Compiled and edited by Edwin Danson, Swan Consultants Ltd., 94.

[5] Rimsky-Korsakov, N. A. (2017). Technisheskie sredstva dlia issledovanija dna akvatorii gidrolokazionnymi metodami. Mejdynarodny jurnal prikladnych I fundamentalnych issledovaniy. № 10-2. S. 205-213.

[6] Sagalevich. (2018). Rol podvodnych apparatov v osvoenii oceana. M : Okeanologija, Tom 18. № 56. S. $982-988$.

[7] Linklater, Amy. Design and Simulation of a Towed Underwater Vehicle. (2005). Thesis submitted to the Faculty of the Virginia Polytechnic Institute and State University in partial fulfillment of the requirements for the degree of Master of Science In Aerospace Engineering. Blacksburg, Virginia, 120 P. Resaved from: https://vtechworks.lib.vt.edu/bitstream/ handle/10919/33622/-AmyThesis.pdf? sequence=1\&isAllowed=y

[8] V. Blintsov, \& P. Kucenko. (2019). Application of systems approach at early stages of designinng unmanned towed underwater systems for shallow water areas. Eastern-European Journal of Enterprise Technologies, 5/9 (101), 15-26. DOI: 10.15587 / 1729-4061.2019.179486

[9] Veltishchev, V., Kropotov, A., \& Chelyshev, V. (1995). Avtomatizatsiya proektirovaniya podvodnykh teleupravlyaemykh kompleksov. Sistemy i tekhnologii avtomatizatsii, 50-52. Resaved from: https://www.cta.ru/-cms/f/326687.pdf

[10] Liskin, V. A., Zaretskiy, A. V., \& Rimskiy-Korsakov, N. A. (2019). Razrabotka glubokovodnykh buksiruemykh sistem dlya issledovaniya pridonnoy oblasti okeana. Nauchnoe obozrenie. Tekhnicheskie nauki. № 1,37-42. Resaved from: URL: https:// science-engineering.ru/ru/article/view?id=1229

[11] Oleksandr Blintsov, Volodymyr Sokolov, \& Pavel Kucenko. (2019). Formulation of Design Tasks of Towed Underwater Vehicles Creation for Shallow Water and Automation of their Motion Control. EUREKA: Physics and Engineering. 2, Pages 30-42. DOI: 10.21303/2461-4262.2019.00854

[12] B. Buckham, Meyer Nahon, Mae L. Seto. (2003) Dynamics and control of a towed underwater vehicle system, part I: Model development. Ocean Engineering. 30(4), 453-470. Resaved from: https://www.researchgate.net/-publication/222698853 Dynamics_and_control_of_a_towed_underwater_vehicle_system_part_I_Model_development

[13] Paul Williams. (2006) Towing And Winch Control Strategy For Underwater Vehicles In Sheared Currents. International Journal of Offshore and Polar Engineering, 16 (03). Resaved from: https://www.researchgate.net/publication/254509097 Towing_And_Winch_Control_Strategy_For_Underwater_Vehicles_In_Sheared_Currents

[14] Blintsov, V. S., \& Kutsenko, P. S. (2020). Henezys tekhnolohii ta shliakhy udoskonalennia proektuvannia ta pobudovy buksyruvanykh pidvodnykh system dlia milkovodnykh akvatorii. Tekhnolohichnyi audyt ta rezervy vyrobnytstva. № 3, 19-27. DOI: 10.15587/2312-8372.2020.202109

[15] Venesa Stanic, Marko Hadjina, Niksa Fafandjel, \& Tin Matulja. (2018) Toward shipbuilding 4.0-an industry 4.0 changing the face of the shipbuilding industry. Brodogradnja. Teorija i praksa brodogradnje i pomorske tehnike, 69 (3), 111-128. DOI: $10.21278 /$ brod69307

[16] Asuma Minowa. (2015). System Analyses and Motion Control of a Towed Underwater Vehicle. Tokyo. University of Marine Science and Technology, 51. Resaved from: https://www.google.com.ua/url?sa=i\&rct=j\&q=\&esrc-=s\&source=im ages\&cd=\&ved=2ahUKEwjC8PnV2dLkAhXxw8QBHabQB1cQjhx6BAgBEAI\&url=https\%3A\%2F\%2Foacis.repo.nii. ac.jp\%2F\%3Faction\%3Drepository_action_common_download\%26item_id\%3D1305\%26item_no\%3D1\%26attribute_ id\%3D20\%26file_no\%3D1\&psig=AÖvaw0aG7ahcQEZhcSxZB6plteh\&ust=1568632507774952 
[17] Volodymyr Blintsov, \& Olexandr Klochkov. (2019). Generalized Method of Designing Unmanned Remotely Operated Complexes Based on the System Approach. EUREKA: Physics and Engineering, 2, 43-51. DOI: 10.21303/24614262.2019.00878

[18] Okeanografitseskie issledovaniya I podvodno-technitheskie raboty na meste gibeli atomnoi podvodnoi lodki "Komsomolets". (1996). M.: Nauka, Publ.

[19] GOST R 56960-2016. Natsionalnyy standart Rossiyskoy Federatsii. Apparaty neobitaemye podvodnye. Klassifikatsiya. Unmanned underwater vehicles. Classification. Resaved from: http://docs.cntd.ru/-document/1200136057

[20] Classification-of-underwater-vehicles. Resaved from: https://www.-researchgate.net/figure/Classification-of-underwatervehicles_fig1_298354381

[21] Buksyruvanyi profilohraf. EdgeTech 3100, Resaved from: http://www.tetis-pro.ru/catalog/edgetech-3100-buksiruemyyprofilograf/

[22] Gubatsek, M. (2000). Titanik. 2-e izd. Minsk : OOO «Popurri», Publ.

[23] Underwater towed vehicle FLAMINGO. https://oio.pg.edu.pl/katedra-projektowania-okretow-i-robotyki-podwodnej/ underwater-towed-vehicle-flamingo?p_1_id=3596274\&p_v_1_s_g_id=0\&

[24] Ballard, Robert D. (2008). New Archaeological Oceanography. Princeton University Press, 287 pages.

[25] CAMPER. Resaved from: https://www.whoi.edu/what-we-do/explore/underwater-vehicles/towed-vehicles/camper/

[26] Video plankton recorder. http://www.vliz.be/en/videoplanktonrecorder-en

\section{СПИСОК ВИКОРИСТАНОЇ ЛІТЕРАТУРИ}

[1] Пронин А.А. Методика сбора и представления материалов видеосъёмки поверхности дна с помощью необитаемого подводного буксируемого аппарата «Видеомодуль». Международный журнал прикладных и фундаментальных исследований. 2017. Вып. № 12 (Часть 1). С. 142-147. URL: https://applied-research.ru/ru/article/view?id=11980.

[2] Towed Vehicle: Undulating Platforms as Tools for Mapping Coastal Processes and Water Quality Assessment. Seaside, California, 2007. Workshop Proceeding. URL: http://aquaticcommons.org/3106/1/ACT_WR07-01_Tower_Vehicles.pdf.

[3] Frank Kirchner, Sirco Straube, Daniel Kuhn, Nina Nouer. Al Technologies for Underwater Robots. Springer Nature Switzerland AG, 2020. URL: https://www.springer.com/gp/book/9783030306823.

[4] Geotechnical \& Geophysical Investigations for Offshore and Nearshore Developments. (2005). International Society for Soil Mechanics and Geotechnical Engineering. Compiled and edited by Edwin Danson, Swan Consultants Ltd., 94.

[5] Римский-Корсаков Н.А. Технические средства для исследований дна акваторий гидролокационными методами. Международный журнал прикладных и фундаментальных исследований. 2017. № 10-2. С. $205-213$. URL: https://www.applied-research.ru/ru/article/view?id=11889.

[6] Сагалевич А.М. Роль подводных аппаратов в освоении океана. М : «Океанология», 2018. Т. 58. № 6. С. $982-988$. URL: http:/csl.isc.irk.ru/BD/Журналы/океанология\%202018г\%20№6/стр\%20982-988.pdf.

[7] Linklater, Amy. Design and Simulation of a Towed Underwater Vehicle. (2005). Thesis submitted to the Faculty of the Virginia Polytechnic Institute and State University in partial fulfillment of the requirements for the degree of Master of Science In Aerospace Engineering. Blacksburg, Virginia, 120 P. Resaved from: https://vtechworks.lib.vt.edu/bitstream/ handle/10919/33622/AmyThesis.pdf?sequence=1\&isAllowed=y.

[8] V. Blintsov, \& P. Kucenko. (2019). Application of systems approach at early stages of designinng unmanned towed underwater systems for shallow water areas. Eastern-European Journal of Enterprise Technologies. 5/9 (101). P. 15-26. DOI: 10.15587/1729-4061.2019.179486.

[9] Вельтищев В., Кропотов А. и Челышев В. (1995). Автоматизация проєктирования подводных телеуправляемых комплексов. Системы и технологии автоматизации, 50-52. URL: https://www.cta.ru/-cms/f/326687.pdf.

[10] Лискин В.А., Зарецкий А.В., Римский-Корсаков Н.А. Разработка глубоководных буксируемых систем для исследования придонной области океана. Научное обозрение. Технические науки. 2019. № 1. C. 37-42. URL: https://scienceengineering.ru/ru/article/view?id=1229.

[11] Oleksandr Blintsov, Volodymyr Sokolov, \& Pavel Kucenko. (2019). Formulation of Design Tasks of Towed Underwater Vehicles Creation for Shallow Water and Automation of their Motion Control. EUREKA: Physics and Engineering. № 2. P. 30-42. DOI: 10.21303/2461-4262.2019.00854.

[12] B. Buckham, Meyer Nahon, Mae L. Seto. (2003). Dynamics and control of a towed underwater vehicle system, part I: Model development. Ocean Engineering. 30 (4). P. 453-470. https://www.researchgate.net/publication/222698853_Dynamics_ and_control_of_a_towed_underwater_vehicle_system_part_I_Model_development.

[13] Paul Williams. (2006) Towing And Winch Control Strategy For Underwater Vehicles In Sheared Currents. International Journal of Offshore and Polar Engineering 16 (03). https://www.researchgate.net/publication/254509097_Towing_And_ Winch_Control_Strategy_For_Underwater_Vehicles_In_Sheared_Currents.

[14] Блінцов В.С., Куценко П.С. Генезис технологій та шляхи удосконалення проєктування та побудови буксируваних підводних систем для мілководних акваторій. Технологічний аудит та резерви виробництва. 2020. № 3. С. 19-27. DOI: $10.15587 / 2312-8372.2020 .202109$.

[15] Venesa Stanic, Marko Hadjina, Niksa Fafandjel, Tin Matulja. (2018) Toward shipbuilding 4.0-an industry 4.0 changing the face of the shipbuilding industry. Brodogradnja : Teorija i praksa brodogradnje i pomorske tehnike. Vol. 69. No. 3. 2018. P. 111-128. DOI: 10.21278/brod69307. 
[16] Asuma Minowa. (2015). System Analyses and Motion Control of a Towed Underwater Vehicle. Tokyo. University of Marine Science and Technology, 51. Resaved from: https://www.google.com.ua/url?sa=i\&rct=j\&q=\&esrc-=s\&source=im ages\&cd=\&ved=2ahUKEwjC8PnV2dLkAhXxw8QBHabQB1cQjhx6BAgBEAI\&url=https\%3A\%2F\%2Foacis.repo.nii. ac.jp\%2F\%3Faction\%3Drepository_action_common_download\%26item_id\%3D1305\%26item_no\%3D1\%26attribute_ id\%3D20\%26file_no\%3D1\&psig=AŌvVaw0̄aG7ahcQEZEhcSxZB6plteh\&ust=1568632507774952.

[17] Volodymyr Blintsov, \& Olexandr Klochkov. (2019). Generalized Method of Designing Unmanned Remotely Operated Complexes Based on the System Approach. EUREKA: Physics and Engineering. № 2. P. 43-51. DOI: 10.21303/24614262.2019.00878.

[18] Океанологические исследования и подводно-технические работы на месте гибели атомной подводной лодки «Комсомолец» (1996). Москва : Наука. 362 с.

[19] ГОСТ Р 56960-2016. Национальный стандарт Российской Федерации. Аппараты необитаемые подводные. Классификация. Unmanned underwater vehicles. Classification. Resaved from: http://docs.cntd.ru/-document/1200136057.

[20] Classification-of-underwater-vehicles. Resaved from: https://www.-researchgate.net/figure/Classification-of-underwatervehicles_fig1_298354381.

[21] Буксируваний профілограф EdgeTech 3100. Resaved from: http://www.tetis-pro.ru/catalog/edgetech-3100-buksiruemyyprofilograf.

[22] Губачек М. (2000). Титаник. 2-е изд. Минск : ООО «Попурри», 608 с.

[23] Underwater towed vehicle FLAMINGO. https://oio.pg.edu.pl/katedra-projektowania-okretow-i-robotyki-podwodnej/ underwater-towed-vehicle-flamingo?p_1_id $=3596274 \&$ p_v_1_s_g_id $=0 \&$.

[24] Ballard Robert D. (2008). New Archaeological Oceanography. Princeton University Press. 287 p.

[25] CAMPER. Resaved from: https://www.whoi.edu/what-we-do/explore/underwater-vehicles/towed-vehicles/camper.

[26] Video plankton recorder. http://www.vliz.be/en/videoplanktonrecorder-en.

(C) П. С. Куценко

Дата надходження статті до редакції: 08.12.2020 Дата затвердження статті до друку: 18.12.2020 